\title{
The Star Wars Negotiation: Is It a Perfect Business Negotiation?
}

\author{
Yue Jing ${ }^{1,{ }^{*}, a, \dagger}$ Kuanjue Shao ${ }^{2, *, b, \dagger}$ Chenzhan Sun $^{3,{ }^{*}, c, \dagger}$ Yujing Wang ${ }^{4, *, d, \dagger}$ \\ ${ }^{1}$ University of British Columbia, Shenzhen, China \\ ${ }^{2}$ Admiral Farragut academy, Dalian, China \\ ${ }^{3}$ Jinan University, Beijing, China \\ ${ }^{4}$ University of Queensland, Beijing, China \\ ${ }^{*}$ Corresponding author. Email: ${ }^{a} y j i n g 04 @ s t u d e n t . u b c . c a,{ }^{b}$ kshao18@farragut2.org, ${ }^{c}$ sun1009@stu2019.jnu.edu.cn, \\ dyujing.wang1@uqconnect.edu.au \\ These authors contributed equally.
}

\begin{abstract}
Business negotiation is an integrated strategic process to generate added values for both parties involved in the negotiation. This study reviews a renowned business acquisition negotiation case that happened between the Walt Disney Company and Lucasfilm. Although this acquisition is financially successful, there are some pitfalls and disputes with respect to this handover in accordance with an aftermath appraisal, especially from the perspective of Lucas. Based on the analysis, this study thereby discusses the techniques applied during the negotiation process. In line with the extant business negotiation theories, some reflections are also made in this paper, which may contribute to the ensuing development of business negotiation theories and practices.
\end{abstract}

Keywords: Business negotiation, business acquisition, Walt Disney, Lucasfilm, trust.

\section{INTRODUCTION}

Business negotiation can be defined as a comprehensive and strategic process to achieve the utmost benefits among different parties involved on the bargaining table [1]. An array of strategies constitute a strategic negotiation, comprised of coordinated business negotiation procedures. Specifically, these procedures need to be carefully managed, from the early-stage market research, to the multiplex communicational tactics in the meeting room, and to the aftermath and reflection of negotiation, all of which [2]. In spite of the complex nature of the business negotiation, the ultimate goal is to create more added values for all the stakeholders involved in this process, i.e., achieves a win-win situation in which all the participants can be satisfied.

Nonetheless, it should be noted that all negotiation cases are essentially distinct, which poses the need to dig into the reality of a certain scenario. Hence, case studies are commonly used in the business negotiation research to shed light on the theoretical and practical development of pertinent domains [1]. This review study would specially focalize on a renowned corporation acquisition case between Walt Disney and Lucasfilm. On October 30, 2012, Walt Disney made a surprising announcement that it has successfully made an agreement with Lucasfilm to acquire $100 \%$ of its shares. This acquisition is worth 4.05 billion US dollars, with the payment method combining cash and stock, reacting as one of the most expensive acquisition cases in the contemporary film industry [3].

Primarily, we present a briefly introduction for both parties in this case. Walt Disney Film is a worldwide famous Hollywood company that has not been traded so far. The Walt Disney Company, named after its founder Walt Disney, is also one of the world's largest multinational company headquartered in the United States. Its film production started in the 1930s and became well-known due to the Mickey Mouse character in the field of live action movies in the 1940s. Contemporarily, after acquiring a number of independent film giants (e.g., Miramax, Pixar, and marvel), Disney has consolidated its position as the top film company not only in the productions of cartoons but all typologies of films [4]. 


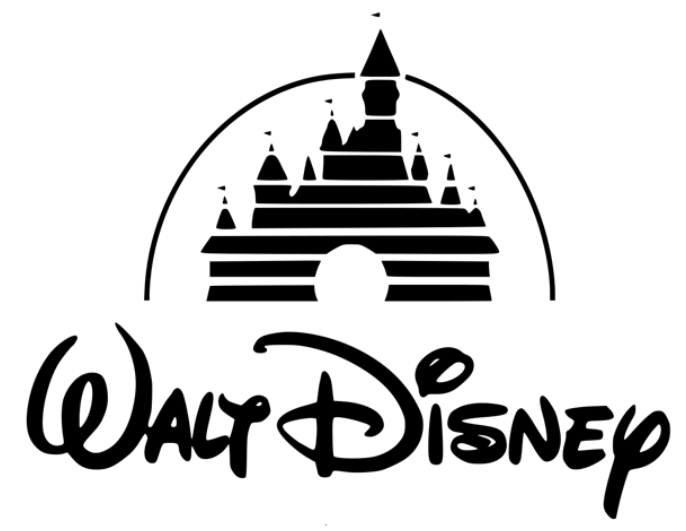

Figure 1 Brand logo of Disney

On the other side, Lucasfilm was founded by one of the most successful Hollywood directors George Lucas, whose "Star Wars" is Hollywood's most famous science fiction series. Besides, Lucasfilm is also the leader in the areas of visual effects, sound effects and computer animation in the film industry [2]. Due to their outstanding expertise, their subsidiaries often assist other film production companies. At the time of the acquisition, Lucas was the chairman and CEO of the company, while Micheline Chau was the president and chief operating officer of the company. Before the acquisition negotiation, Lucasfilm had cooperated with Disney on several projects, such as establishing the Star Wars theme park in Disneyland. As a result, Lucas personally had a very good relationship with Disney as well.

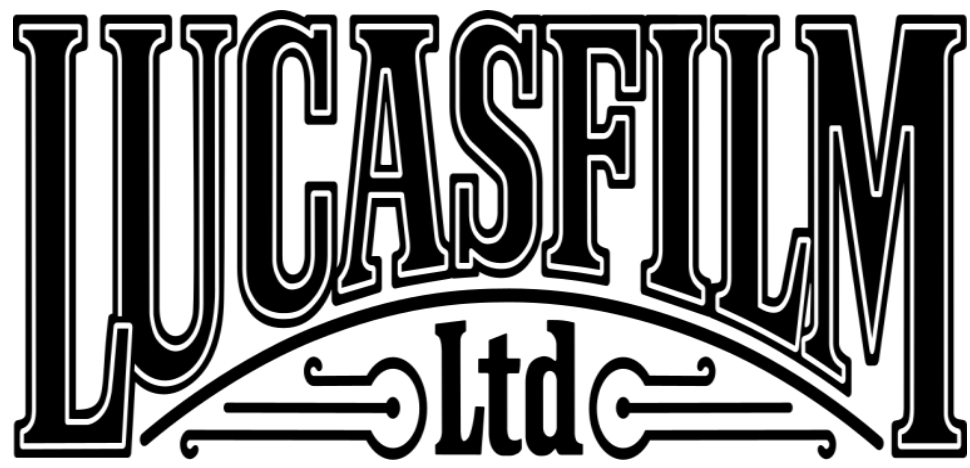

Figure 2 Brand logo of Lucasfilm

As for the occurrence of this acquisition, it can be traced back to May 2011, Robert Iger, CEO of Disney Company, had breakfast with Lucas. They had a casual conversation about whether Lucas would like to sell his company, as Lucas just had recently celebrated his 67th birthday and was already thinking seriously about the retirement. After that meal, Lucas deemed that the sale of his company would be inevitable. Then, he told Iger that once he made a final decision, he would be very happy to transfer his company to Disney. In June 2012, Lucas called Iger to commence the negotiation process.

After one year and five months of negotiations, Lucas agreed with the business acquisition plan proposed by Disney, as he thought that the proposal can cater to both his financial needs and the future development of the Star Wars films series. As a consequence, at the end of October of 2012, Iger arranged for Lucas to fly to Disney's headquarters in Burbank to finally signed the document. On October 31, Disney announced the acquisition of Lucasfilm. After the acquisition, Disney has already put forward a series of Star Wars films (Star Wars 7, 8, and 9) and lots of peripheral products.
After the acquisition, as can be seen from the stock value of Disney, this negotiation is definitely a very successful case. Nevertheless, based on the recent interviews with Lucas, there shows that some dissatisfaction is lingering. Therefore, it is quite meaningful to get back to this case and look into what really happened during the negotiation, the reflections of which would shed light on the future business negotiation process. Before that, it is necessary to review what are the interests of both sides of the negotiation, which is the key to manage the following negotiation strategies.

\section{INTERESTS OF BOTH PARTIES}

The interest analysis is the premise for any business negation [5]. It is considered that people would make decisions based on their embedded and invested interests. In other words, when their interests are met in a negotiation, it is very likely to reach a consensus. Otherwise, compromises and trade-offs have to be made in order to reach an agreement. 
As can be concluded in this case, Disney's interest would be more about profit-making and anything that will make Disney become more competitive in the film industry [6]. By acquiring Lucasfilm, Disney can create more contents related to the Star Wars series, which is one of the most prominent cultural assets of Hollywood. More specifically, with the copyrights of Star Wars, Disney can not only continue to create Star Wars related films, but also make more merchandises and peripheral products (e.g., shirts, toys, and CDs), which could even become the primary income sources. In addition, with the popularity of Star Wars, Disney can create new rides in Disney world to attract more Star Wars fans to their theme parks. Overall, the acquisition of Lucasfilm is a long-term strategic plan for Disney to make profits and enhance its competitive advantages. As indicated in their financial report, after five years of the acquisition, Disney had already made their money back from the four movies that have been released, which somehow proved their intentions.

From the perspective of Lucasfilm, the interests can be divided into two dimensions: one is related to the founder Lucas himself and the other is pertinent to the prospect of Star Wars. Personally, Lucas was in his late 60 s and wanted to retire as well as focus more on his family and personal life. Additionally, Lucas still hoped that he could keep his influences on Lucasfilm and keep the Star Wars more universe. To achieve his needs, Lucas put forward numerous criteria as the premise of the acquisition. As George Lucas had put in his lifetime works into Star Wars, he only wanted to sell his company to an organization that could handle it well. All in all, he did not have any regrets about the transfer of the company.

According to the interest analysis, it can be concluded that Disney has to provide Lucasfilm with ample financial benefits and convince Lucas that Disney would ensure that the Star Wars can keep its popularity in the negotiation process. By satisfying these two premises, the business negotiation is expected to lead to the success of the acquisition.

\section{Analysis of the Negotiation Process}

The negotiation started at the beginning of 2011. In order to build the trust, Iger decided to conduct the market research and perform the following negotiation by himself, which indicates that Disney considered this acquisition very seriously and significantly. This decision provided a ground for Disney to build the trust with Lucas [6].

At the preparation stage of the negotiation, Iger and Disney were well prepared for the acquisition of Lucasfilm with both decisive determination and comprehensive design of strategies. For instance, before the negotiation, he spent a lot of time on studying "Star Wars", including the film scripts and every character in the movie [6]. He watched the movie again and again and took a lot of notes. All these efforts are made to show that he has a determination to understand the Lucasfilm.

Then, during the first negotiation in 2011, Iger demonstrated a very good and sincere attitude by actively listening to all the needs from Lucas, including his plans and interests, without any interrupting or rushing to the results. This reveals that Iger adopted a collaborative (interest-based) negotiation rather than competitive (distributed) negotiation strategy [7], which is a more effective way of negotiation to achieve the goals of both parties, especially when the other side is powerful. Besides, Iger also showed great patience during the negotiation. In fact, Iger conducted the deal over the course of a year and a half to ensure that Disney is a trustworthy and determinant company for this acquisition [8].

Meanwhile, to fulfil Lucas' needs of controlling the Star Wars and being respected, Iger orally agreed that Disney would hire him as a consultant and plan to refer to his visions and suggestions about the following issues of Star War film [8]. This is a very crucial decision that directly leads to the agreement of Lucas. However, it also turns out to be the trickiest approach made by Iger. In general, Iger successfully convinced Lucas that Disney is the best choice for him and there would have no problems in terms of the following management of the Star War film.

Thus, it can be said that it is a very effective and successful business negotiation case when just looking at the negotiation process. Yet, in the following years, there started to emerge some divergences and disputes between Lucas and Disney, which are delineated in the next section.

\section{Aftermath of the Negotiation}

After the acquisition of Lucasfilm, as the market has expected, Disney has made a lot of accomplishments from the Star Wars movies series [9]. It can be said that Disney has very successfully in terms of meeting the objectives of this business negotiation and the BATNA [10]. Especially from the perspective of financial performance, it is definitely a huge achievement for Disney. However, after the hand-over, Lucas was not totally satisfied with the results. During an interview with Lucas, he has told the media that he felt "betrayed" about Disney's handling of Star Wars movies [9].

Based on the previous studies, this situation occurred mainly due to the change of Lucas' personal interests and needs $[2,9]$. At the very beginning, Lucas focused more on his retirement and wanted to spend more time on his personal and family life. However, as time went by, he started to transform his attentions back to the movie and gradually began to try to take control of the movies of Star Wars [9].

This transition is manifested by a dispute between Lucas and Disney on the script cooperation. Although Iger has agreed that Lucas can have a say in the story 
script writing and promised him to act as a consultant for all the Star Wars films, Disney replaced Lucas's handpicked screenwriter eventually. This has been considered as a very controversial point, as the promise made by Iger was just an informal agreement and was not legally binding in the contract. As shown in the acquisition agreement, it is stated that Disney always has the final decision-making rights to the Star Wars film, making Iger's promise more like a friendly oral agreement [10].

Therefore, looking back at this business negotiation, it can be summed that Disney and Iger have adopted a very wise negotiation strategy. In order to ensure their benefits can be guaranteed and the acquisition can be made, they have blurred some of the terms in the contract, by taking advantages of the trust with Lucas [10]. Assuming that the best result for any business negotiation is a win-win scenario, the negotiation between Disney and Lucas cannot be considered as "perfect". As a matter of fact, Disney has gained more benefits as a result of their well-design negotiation strategies.

\section{CONCLuSiON}

In conclusion, it is found that Disney and Iger have made a very delicate plan for this acquisition, by adopting step-by-step business negotiation techniques to avoid any common pitfalls during the negotiation. This strategic negotiation strategy starts from the desk research that aims to understand the needs and demands of the Lucasfilm to the trust-building during the negotiation process [6]. As a result, due to the high level of mutual trust, the negotiation process was conducted in an effective and efficient manner.

In comparison, Lucas cannot be called as a "wise businessman" and does not notice the pitfall when handling the specific terms in the contract. It could be ascribed as the main cause of his struggling and dissatisfaction after the acquisition [7]. However, the change of his interest after the acquisition could also be criticized. In nowadays interest-based business negotiation, only a comprehensive understanding of the needs and interests of both sides of negotiation can lead to a successful deal.

To sum up, the acquisition of Lucasfilm by Disney illustrates the importance of building trust when dealing with a powerful counterpart according to our analysis. Nevertheless, no matter what level the trust exists between the two parties, intensive and extensive attentions have to be paid into the terms of contracts. All these terms must be carefully appraised to examine whether the core interests can be formally guaranteed. After all, the trust may fade away as time goes by, while the only valid thing would be what has been written on the paper. These results offer a guideline for the entrepreneurs to applying in their future negotiations and acquisition.

\section{REFERENCES}

[1] Jang, D., Elfenbein, H. A., \& Bottom, W. P. (2018). More than a phase: Form and features of a general theory of negotiation. Academy of Management Annals, 12(1), 318-356.

[2] Proctor, W. (2013). Holy crap, more Star Wars! More Star Wars? What if they're crap?": Disney, Lucasfilm and Star Wars online fandom in the 21st Century. Journal of Audience and Reception Studies, 10(1), 198-224.

[3] Carillo, C., Crumley, J., Thieringer, K., \& Harrison, J. S. (2012). The Walt Disney Company: A Corporate Strategy Analysis.

[4] Proctor, W., \& Freeman, M. (2016). 'The First Step into a Smaller World': The Transmedia Economy of Star Wars.

[5] Wasko, J. (2020). Understanding Disney: The manufacture of fantasy. John Wiley \& Sons.

[6] Gray, C. (2015). Journey to Star Wars: The Force Awakens: Lost Stars. Disney Electronic Content.

[7] Proctor, W., \& McCulloch, R. (Eds.). (2019). Disney's Star Wars: Forces of Production, Promotion, and Reception. Fandom \& Culture.

[8] Golding, D. (2019). Star Wars after Lucas: A Critical Guide to the Future of the Galaxy. U of Minnesota Press.

[9] Jewell, J. (2015). How Disney will make US \$5 billion from Star Wars 7 merchandise. The Conversation, 2015(21 Sep).

[10] Kent, M. (2019). You Die! You Know That, Right? You Don't Come Back!. Disney's Star Wars: Forces of Production, Promotion, and Reception, 221. 